\title{
Physico-Chemical Characteristics of the Biofertilizer Produced Anearobically in a Biodigester Using Poultry Litter as Substrate
}

\author{
Sideney Becker Onofre ${ }^{1,2^{*}}$, Ivan Carlos Bertoldo ${ }^{1,2}$, Dirceu Abatti ${ }^{2}$ and Douglas Refosco ${ }^{2}$ \\ ${ }^{1}$ Universidade Comunitária da Região de Chapecó - UNOCHAPECÓ - Centro de Ciências \\ Exatas e Ambientais - CEA - Programa de Pós-graduação em Tecnologia e Gestão da \\ Inovação - PPGTI - Av. Senador Attílio Fontana, 591-E EFAPI - 89809-000 - \\ Chapecó - Santa Catarina - Brasil \\ ${ }^{2}$ União de Ensino do Sudoeste do Paraná - UNISEP - Av. União da Vitória, 14 - Bairro \\ Miniguaçu - 85605-040 - Francisco Beltrão - Paraná - Brasil \\ *Corresponding author
}

\section{A B S T R A C T}

Raising confined poultry generates waste that causes environmental problems, and that requires special handling in order to minimize these impacts. Poultry litter contains bird

Keywords

Agricultural

Waste, Poultry

Farming,

Biofertilizers,

Ecology.

Article Info

Accepted:

25 January 2017

Available Online:

10 February 2017 feces and feathers, spilled feed and the moisture-absorbing material used on the floor of the cages. This results in a residue with a high concentration of nutrients that may impact the soil due to the wide availability of poultry litter. The poultry litter and the produced biofertilizer was characterized chemically and subsequently evaluated in three treatments, namely: T1 - poultry litter + cattle biofertilizer + water; T2 - poultry litter + biofertilizer, and T3 - poultry litter + water, so as to determine the three treatments' ability to produce biogas. The obtained results reveal that the poultry litter is composed of nitrogen, phosphorus, potassium, calcium, magnesium and sulfates. The produced biofertilizer proved to be rich in macro and micronutrients, highlighting nitrogen, phosphorus, potassium, calcium, magnesium, sodium, iron, boron, copper, zinc and manganese. The $\mathrm{pH}$ of the biofertilizer varied from 6.58 to 8.02. The macro and micronutrients of the produced biofertilizers differed statistically among themselves in the effluents evaluated in relation to the affluent of the system. The levels of nitrogen and phosphorus were the ones with the highest results in the PL+B treatment, differing significantly from the treatments $\mathrm{PL}+\mathrm{B}+\mathrm{W}$ and PL+A. This allows for the conclusion that the use of poultry litter biomass is a viable alternative for the production of biogas and biofertilizers, potentially replacing the use of chemical fertilizers in the poultry farms.

\section{Introduction}

Intensive poultry farming generates a significant amount of waste, among which the waste resulting from the slaughter and processing of animals and from the poultry or chicken litter, should be highlighted. This litter contains bird feces and feathers, spilled feed and the moisture-absorbing material used on the floor of the cages, resulting in a residue with a high concentration of nutrients.

The high concentration of poultry litter in some regions where the soil and the extraction 
of nutrients by crops is insufficient to recycle it, is causing environmental contamination by nutrients, pathogenic micro-organisms and chemical residues with economic, environmental and public health repercussions.

According to Hahn (2004), the two elements present in high concentrations in poultry littter that are most linked to environmental contamination, are nitrogen and phosphorus. The high concentration of nitrogen can contaminate the air, soil, surface water and groundwater. Phosphorus may contaminate the soil and, mainly, the surface waters. The high concentration of nutrients, organic material and the constant deposition of feces by the animals provide poultry litters with favorable substrate characteristics for the maintenance and development of a large and diverse microbial population in the excretions and absorbent material, provided that it is managed properly and without pollutants. To minimize the environmental impacts, the poultry farmer has been guided toward increasing the use of the same poultry litter in several batches, bundling them (fermentation) before reuse or before its application as fertilizer or biofertilizer.

The production of biofertilizers is a result of the fermentation process, i.e. the activity of microorganisms in the decomposition of organic matter and complexation of nutrients, which can be obtained by simply mixing water and fresh manure (Timm et al., 2004).

Biofertilizers have bioactive compounds resulting from the biodigestion of organic compounds of animal and plant origin. Its contents include living or latent microorganism cells with aerobic and anaerobic metabolisms and fermentation (bacteria, yeasts, algae and filamentous fungi), in addition to organomineral metabolites and chelates in aqueous solutes
(Pinheiro and Barreto 1996). According to Santos and Akiba (1996), the metabolites are compounds of proteins, enzymes, antibiotics, vitamins, toxins, phenols, esters and acids, including those with phyto-hormone activity, produced and released by micro-organisms.

The production of the biofertilizer occurs through fermentation processes that can be completed in 30 days in summer, or 45 days in winter. According to Meirelles et al., (1997), temperature is one of the most important factors in fermentation. In biofertilizers produced from biomass associated with animal manure, the best temperature is $38^{\circ} \mathrm{C}$, which is the temperature of the digestive system of ruminants. In some hot regions of the Northeast of Brazil, the product can be produced in 14 days. In places where the average temperature is $18^{\circ} \mathrm{C}$, it can take up to 90 days when done in the winter. Meirelles et al., (1997) also emphasize that the lack of fermentation may be associated with the contamination or sudden change of the compound, or with the fact that the manure came from animals treated with antibiotics.

The bacterial decomposition of organic matter under anaerobic conditions takes place in three stages: 1) Hydrolysis stage; 2) Acid stage, and 3) Methanogenic stage. At the hydrolysis stage, the bacteria release so-called extracellular enzymes into the medium. These will promote the hydrolysis of the particulate matter and transform the larger molecules into smaller molecules that are soluble in the medium (Steil, 2001). The behavior of this process can be seen in Figure 1.

In the acid stage, acid producing bacteria transform greasy proteins and carbohydrates into organic acids (lactic acid, butylic acid), ethanol, ammonia, hydrogen, carbon dioxide and others. And finally, in the third stage, the methanogenic bacteria act on the hydrogen 
and carbon dioxide, transforming them into methane gas $\left(\mathrm{CH}_{4}\right)$ (Sanchez et al., 2001).

After passing through the digester, the residues have a high quality for use as agricultural fertilizer, mainly because of the following aspects: reduction of the material's carbon content, since the organic matter exclusively loses carbon in the form of $\mathrm{CH}_{4}$ and $\mathrm{CO}_{2}$ during the digestion, increasing the content of nitrogen and other nutrients and decreasing the $\mathrm{C} / \mathrm{N}$ ratio, which improves the conditions of the material for agricultural purposes; increases in the ability of microorganisms to fix the biofertilizer in the soil, since the material is already in an advanced state of decomposition, which increases the efficiency of the biofertilizer and the partial solubility of some nutrients (Seixas et al., 1980).

The decomposition treatment of poultry litter before it is used as biofertilizer deserves increased emphasis because it gives this treatment the possibility of reducing or even eliminating pathogens and chemical residues. However, few studies have been developed to investigate the transformations that occur in poultry litter during this process, and to verify the effectiveness of this decomposition in reducing its potential for environmental pollution (Pinheiro and Barreto, 1996; Santos and Akiba, 1996; Souza and Resende, 2003).

There is significant doubt among growers, technicians and companies about the use of this waste as soil fertilizer. In the absence of knowledge or more reliable information backed up by scientific evidence, certifying companies of organic agriculture have adopted different recommendations for the treatment of these residues prior to applying them to the soil. As such, some of them require a period of up to 180 days for decomposition of the material as a precautionary measure. Other certifying companies, on the other hand, unconditionally prohibit their use as biofertilizer. Giving an alternative destination to these residues is appropriate, and their use as a source of energy is becoming essential (Fernandes and Martins, 1999; Fernandes and Testezlaf, 2002).

Discussing and evaluating the aspects that involve the use of poultry litters in power generating sources is the objective of this work. The starting point is the assumption that poultry litters are an excellent source of energy after going through anaerobic fermentation processes and generating residues that can be used as fertilizers in agricultural areas of the South West Region of Paraná, Brazil, so as to comply with the legal regulations that prevent their direct use in the soil.

In this context, this study aimed to evaluate the physico-chemical composition of the biofertilizer resulting from the anaerobic process for it to be used as agricultural biofertilizer.

\section{Materials and Methods}

The poultry litter was obtained from a conventional chicken production barn of $1,200 \mathrm{~m}^{2}$ installed in a rural property located at the geographic coordinates $25^{\circ} 44^{\prime} 06^{\prime}$ ' $\mathrm{S}$ and $53^{\circ} 04^{\prime} 52^{\prime}$ ' $\mathrm{W}$ in the municipality of Dois Vizinhos - Paraná - Brazil. Three batches of litter from chickens reared for 40 days, on average, were used.

The biofertilizer under study was obtained after going through an anearobic fermentation process in a biodigester following the methodology described in Caetano (1991) and adapting it to this work, in which the employed biodigester was of the Batch type with capacity of 60 liters, which was filled one time in each of the experiments, keeping 
it in fermentation for a period of 56 days, with the material being discharged after the end of the effective period of biogas production. The biodigester was developed by LACTEC Institute of Technology for the Development of Paraná - Curitiba - Paraná - Brazil, and was intended for teaching purposes. It was adapted for the application of the methodology of this study.

All analyses were performed at the Soil Laboratory of the Instituo Agrônomico do Paraná - IAPAR, located at Rodovia Celso Garcia Cid, km 375 - 86047-902 - Londrina Paraná - Brazil.

The tests were carried out between the months of May 2012 and March of 2014, with a minimum temperature of $15^{\circ} \mathrm{C}$ and a maximum of $37^{\circ} \mathrm{C}$, according to Simepar. During this period, the following tests were performed: $1^{\text {st }}$ test: Poultry Litter + Water $[\mathrm{PL}+\mathrm{W}] 1$. Implementation period: May to September to November 2012. $30 \mathrm{Kg}$ PL + 30 kg W. $2^{\text {nd }}$ test: Poultry Litter + Water $-[P L+$ W]2. Period of implementation: October 2012 to March 2013. $15 \mathrm{Kg} \mathrm{PL}+45 \mathrm{~kg} \mathrm{~W} .3^{\text {rd }}$ test: Description of treatments: Period of implementation: September 2013 to March 2014. T1 - Poultry Litter + Biofertilizer + Water, $(\mathrm{PL}+\mathrm{B}+\mathrm{W})$ - of which: $28.25 \mathrm{~kg}$ of water $+28.25 \mathrm{~kg}$ of biofertilizer $+3.5 \mathrm{~kg}$ of litter. T2 - Poultry Litter + Biofertilizer $(\mathrm{PL}+\mathrm{B})$ - of which: 56.5 of biofertilizer +3.5 $\mathrm{kg}$ of litter. T3 - Poultry Litter + Water $(\mathrm{PL}+\mathrm{W})$ - of which: 56.5 of water $+3.5 \mathrm{~kg}$ of litter.

The analyses of macro and micronutrients were carried out in three liquid samples of the affluents and effluents. To this end, the samples were digested using the Digesdahl $®$ digester supplied by Hach, which promotes the total digestion of organic matter based on sulfuric acid $\left(\mathrm{H}_{2} \mathrm{SO}_{4}\right)$, with the later addition of $10 \mathrm{~mL}$ of hydrogen peroxide $\left(\mathrm{H}_{2} \mathrm{O}_{2}\right)$ at up to $440^{\circ} \mathrm{C}$, obtaining a translucent liquid, or extract. With this extract, the levels of nitrogen, phosphorus, potassium, calcium, magnesium, Copper, Manganese, Zinc, and Sodium can be determined (Bataglia, 1983).

To determine the nitrogen levels, the Kjeldahl method was used with a micro distiller, which is based on the transformation of ammoniacal nitrogen into ammonia, which is fixed by the boric acid and titrated with $\mathrm{H}_{2} \mathrm{SO}_{4}$ until the new formation of $\left(\mathrm{NH}_{4}\right) 2 \mathrm{SO}_{4}$, in the presence of the acid/base indicator, according to the methodology described by Silva (1983).

The phosphorous levels were determined with the colorimetric method using a spectrophotometer. This method is based on the formation of a yellow composite of the phosphoric vanadomolybdate system with an acidity of 0.2 to $1.6 \mathrm{~mol} / \mathrm{L}$, in which the developed color is measured by determining the concentration of phosphorus in the samples through the previously drawn line pattern from known concentrations, between 0 and $52 \mu \mathrm{g}$ de $\mathrm{P} / \mathrm{mL}$. The patterns were prepared according to the methodology described by Malavolta (1991).

The atomic absorption was performed with a device model GBC 932 AA coupled to a computer running the software GBCAA. In it, the digested samples were compared with standard extracts according to the element under study. The concentration of calcium, magnesium, potassium, copper, iron, manganese, zinc and sodium were determined this way.

The data was submitted to analysis of variance (ANOVA), and the means and standard deviations were calculated, through which it was possible to compare one data set at the same time. The means obtained were compared by Tukey's test. A significance level of $5 \%(\mathrm{P}<0.05)$ was used for all 
analyses. All trials were carried out using eight samples.

\section{Results and Discussion}

To facilitate the reading of the discussion, this work first presents the chemical composition of the poultry litter, which can present a high variation in its composition depending on its origin. It is worth noting that the vast majority of works does not present the chemical composition of the raw material used in the production of the biofertilizer.

Next, following the main objective of this work, the physico-chemical characteristics of the obtained biofertilizers are presented. The chemical characteristics of the poultry litter produced in the South West region of Paraná are presented in Table 1 and in Figure 2.

By comparing the values obtained in this work with the values observed for poultry litters analyzed in the region of Londrina by Carneiro et al., (2004), one can see that the values are similar and that they don't differ statistically according to the Tukey Test at the level of significance of $5 \%$, corroborating the results obtained.

One can also see that, compared with the data from NCSU (2003) and from Bellaver and Palhares (2003), the results obtained in this study reveal that the poultry litter produced in the Southwest region of Paraná, Brazil, has lower nitrogen levels than that produced in the United States of America, since the data from these two studies show that in the USA the poultry litter reaches levels of $33.00 \mathrm{~g} / \mathrm{kg}$ of dry matter.

The physico-chemical characteristics of the affluents and effluents obtained from the fermentation processes, under anaerobic conditions using the three treatments: T1 poultry litter + biofertilizer from bird waste + water, $(\mathrm{PL}+\mathrm{B}+\mathrm{W})$; $\mathrm{T} 2$ - poultry litter + biofertilizer from bird waste $(\mathrm{PL}+\mathrm{B})$ and $\mathrm{T} 3$ poultry litter + water $(\mathrm{PL}+\mathrm{W})$, are summarized in Table 2.

When analyzing the data in table 2 , one can see that, in general, the treatments did not differ statistically between themselves regarding the levels of macro and micronutrients in the evaluated effluents. The levels of nitrogen and phosphorus, observed for the treatment of PL+B, were the ones with the highest results, differing statistically from the treatments $\mathrm{PL}+\mathrm{B}+\mathrm{W}$ and $\mathrm{PL}+\mathrm{W}$.

When comparing the affluent with the effluent, the output levels of micronutrients were the ones that had more variation when compared with the affluent material, especially in the case of copper and zinc.

The levels of $\mathrm{N}$ and $\mathrm{P}$ were the most significant in the $\mathrm{PL}+\mathrm{B}$ treatment, with higher values being observed in the effluent in relation to other nutrients, which reveals that the minerals became much more concentrated in this type of treatment and that the organic matter was extracted in the form of biogas. It's important to note that the increase in the concentration of nutrients may contribute to the increase in biogas production because it will offer a more favorable medium for the development of anaerobic microorganisms, in addition to enabling the achievement of an effluent with a higher concentration of fertilizing elements.

The data obtained are in line with the findings of Santos (1992), who reported that, regarding the analytical part of its composition, the biofertilizer has macro and micronutrients that can be assimilated by plants, such as: nitrogen, phosphorus, potassium, calcium, magnesium, sulfur, sodium, iron, chlorine, silica, molybdenum, boron, copper, zinc and manganese. Its $\mathrm{pH}$ can vary from 7.0 to 8.0 
and can also be lower when the fermentation is incomplete (Santos, 1992). The final $\mathrm{pH}$ observed in this study was 7.81 to 8.02 , which shows that the anaerobic fermentation process was complete.

The decomposition of the organic compounds of poultry litter depends on numerous factors, which either accelerate or slow it down.
Among these factors, the rate of oxygenation (aeration), ambient temperature, humidity, particle size and the concentration of nutrients should be highlighted. These factors will determine the predominant metabolic oxidation process of organic matter and, consequently, the amount of energy released by these reactions and the amount of nutrients lost (Ancona and Moñoz, 1994).

Table.1 Chemical composition of the poultry litter obtained from 45 samples of the south west region of Paraná in comparison with the literature

\begin{tabular}{ccccccc}
\hline \multicolumn{7}{c}{$\mathrm{g} / \mathrm{kg}$ of dry matter } \\
\hline Samples & $\mathrm{N}$ & $\mathrm{P}$ & $\mathrm{K}$ & $\mathrm{Ca}$ & $\mathrm{Mg}$ & $\mathrm{SO}_{4}$ \\
1 & $26.6 \pm 12.6 \mathrm{a}^{\#}$ & $13.6 \pm 5.6 \mathrm{a}$ & $26.3 \pm 12.6 \mathrm{a}$ & $23.6 \pm 14.2 \mathrm{a}$ & $5.0 \pm 1.2 \mathrm{a}$ & $4.8 \pm 2.5 \mathrm{a}$ \\
2 & $20.2 \pm 09,4 \mathrm{~b}$ & $13.6 \pm 3.7 \mathrm{a}$ & $23.4 \pm 15.4 \mathrm{a}$ & $23.3 \pm 10.6 \mathrm{a}$ & $6.7 \pm 2.2 \mathrm{a}$ & $4.5 \pm 1.8 \mathrm{a}$ \\
\hline
\end{tabular}

* Values given in grams / kilogram of dry matter. " Values followed by the same small-case letter vertically, do not differ by Tukey's Test at the level of significance of 5\%. 1 - Samples collected in the southwest region of Paraná- Brazil. 2 - Data supplied by Carneiro et al., (2004). Poultry litter from the region of Londrina, Paraná, Brazil.

Table.2 Physico-chemical characteristics of the biofertilizer produced anaerobically in a biodigester using poultry litter as substrate. Values calculated based on wet matter*

\begin{tabular}{|c|c|c|c|c|c|c|}
\hline \multirow{2}{*}{ Parameters } & \multicolumn{3}{|c|}{ Affluent } & \multicolumn{3}{|c|}{ Effluent $^{\#}$} \\
\hline & $\mathrm{PL}+\mathrm{B}+\mathrm{W}$ & $\mathrm{PL}+\mathrm{B}$ & $\mathrm{PL}+\mathrm{W}$ & $\mathrm{PL}+\mathrm{B}+\mathrm{W}$ & $\mathrm{PL}+\mathrm{B}$ & $\mathrm{PL}+\mathrm{W}$ \\
\hline $\mathrm{Ng} / \mathrm{L}$ & 9.21 & 12.53 & 8.45 & $15.02 \mathrm{~b}$ & $19.23 \mathrm{a}$ & $13.65 b$ \\
\hline $\mathrm{P} \mathrm{g} / \mathrm{L}$ & 11.08 & 20.12 & 15.95 & $15.04 b$ & $20.27 \mathrm{a}$ & $18.84 \mathrm{ab}$ \\
\hline $\mathrm{P} \mathrm{g} / \mathrm{L}$ & 8.46 & 9.32 & 5.89 & $14.26 \mathrm{a}$ & $15.01 \mathrm{a}$ & $10.34 b$ \\
\hline $\mathrm{P} \mathrm{g} / \mathrm{L}$ & 8.23 & 13.25 & 14.45 & $30,20 b$ & $38.76 \mathrm{a}$ & $39.25 \mathrm{a}$ \\
\hline $\mathrm{P} g / \mathrm{L}$ & 6.68 & 10.56 & 9.53 & $15.99 b$ & $18.43 \mathrm{a}$ & $19.65 a$ \\
\hline $\mathrm{Na} g / \mathrm{L}$ & 11.21 & 9.24 & 8.20 & $15.00 \mathrm{a}$ & $11.98 \mathrm{~b}$ & $13.55 b$ \\
\hline $\mathrm{Fe} \mathrm{mg} / \mathrm{L}$ & 6.45 & 4.02 & 4.23 & $9.08 \mathrm{c}$ & $16.23 \mathrm{a}$ & $11.98 b c$ \\
\hline $\mathrm{Mn} \mathrm{mg} / \mathrm{L}$ & 1.54 & 1.35 & 1.43 & $2.56 \mathrm{~b}$ & $5.02 \mathrm{a}$ & $4.99 \mathrm{a}$ \\
\hline $\mathrm{Cu} \mathrm{mg} / \mathrm{L}$ & 0.56 & 0.96 & 1.02 & $1.02 \mathrm{~b}$ & $3.67 \mathrm{a}$ & $2.56 \mathrm{ab}$ \\
\hline Zn mg/L & 4.32 & 4.56 & 3.98 & $8.79 b$ & $13.65 \mathrm{a}$ & $9.86 b$ \\
\hline $\mathrm{pH}\left(\mathrm{CaCl}_{2}\right)$ & 6.58 & 6.76 & 6.66 & $7.81 \mathrm{a}$ & $8.02 \mathrm{a}$ & 7.98a \\
\hline
\end{tabular}

*Values represented by the means of 8 samples. ${ }^{\#}$ Means followed by the same letter horizontally do not differ by Tukey's Test at the level of significance of $5 \%$. 
Figure.1 Simulation of the cell growth kinetics and the metabolite production during the fermentation for obtaining the biofertilizer

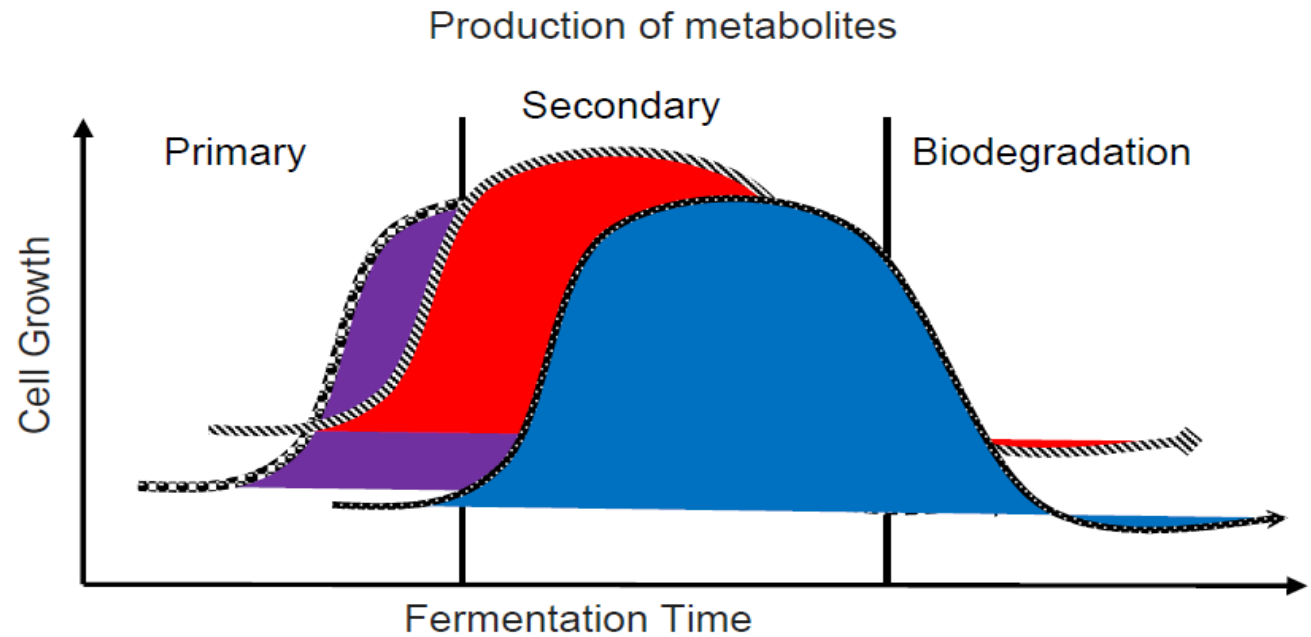

Table.2 (1) Chemical composition of the poultry litter obtained from 8 samples of the south west region of Paraná - Brazil. 2 - Data supplied by Carneiro et al., (2004). Poultry litter from the region of Londrina - Paraná - Brazil

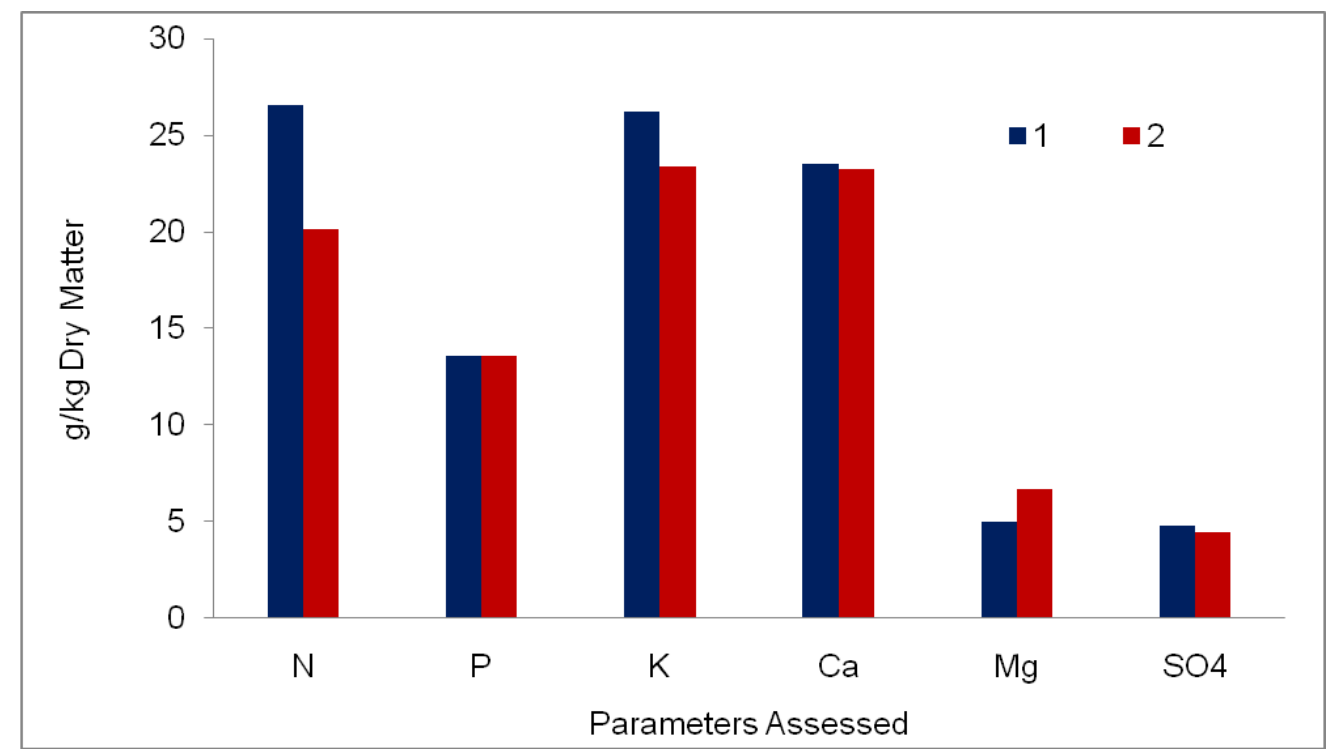

The association of poultry litter + biofertilizer is of great importance to the grower who not only works with the creation of birds and/or cattle, but also with systems that integrate crop-livestock, minimizing costs with chemical fertilizers and using biofertilizer as an alternative source on the property.
When the chemical composition is concerned, the biofertilizer presented macro and micronutrients that could be assimilated by plants, such as: nitrogen, phosphorus, potassium, calcium, magnesium, sodium, iron, boron, copper, zinc and manganese. Its $\mathrm{pH}$ may vary from 6.6 to 8.0, suggesting that 
the fermentation process was adequate, given that lower $\mathrm{pH}$ values are indicative of incomplete fermentation (Santos, 1992).

It should be noted that the composition, quantity and characteristics of the poultry litter vary according to the material, density, duration of the cycle, number of batches created, and storage time, in addition to the techniques used to handle the birds and environmental and physiological factors. These variations will produce different concentrations of macro and micronutrients in the litters, which will influence the anaerobic biodigestion process and the quality of the biogas and the biofertilizer.

There are few studies on the chemical composition of biofertilizers and most cite the pioneering results obtained by Santos (1991). Castro and Hiroce (1988), observed variations in the chemical composition of the aqueous extracts of cattle and poultry manure. In biofertilizers obtained from poultry litter, used to spray deteriorating grapevines, and found the following composition: $5 \mathrm{~g}(\mathrm{~B}) / \mathrm{kg}$; $10 \mathrm{~g}(\mathrm{Mg}) / \mathrm{kg} ; 30 \mathrm{~g}(\mathrm{Zn}) / \mathrm{kg} ; 20 \mathrm{~g}(\mathrm{Mn}) / \mathrm{kg} ; 38$ $\mathrm{g}(\mathrm{S}) / \mathrm{kg} ; 100 \mathrm{~g}(\mathrm{~N}) / \mathrm{kg} ; 0,4 \%$ of amino acids; $0.1 \%$ of nucleic acids and traces of organic acids.

In general, the studies don't present the chemical composition of the final product, but because it is fermented and is based on organic matter, the final product almost always has all elements necessary for plant nutrition in its composition (Santos, 1991; Tratch, 1996; Bettiol et al., 1998).

As such, the liquid biofertilizer obtained from the fermentation of poultry litters can be used in several ways, with the most efficient method being its application in the leave sprays, which have a faster effect (Santos, 1991; Souza and Resende, 2003).
It should be noted that the solid part of the biofertilizer, i.e. the material that stays behind in the sieve after filtering for use of the liquid in the field, also is an excellent source of organic matter and nutrients that can be applied to the soil (Santos, 1992; Bettiol et al., 1998; Souza and Resende, 2003).

The use of poultry litters as biofertilizer is therefore economically desirable, since it represents an internal asset of the rural property containing a high concentration of nutrients. In many properties, it is the only source of nutrients added to the soil by growers. From an ecological point of view, however, there are major restrictions on its use, since this residue can pollute the soil and surface and groundwater.

The best biodigestion systems and techniques are arousing the interest of growers today because they are considering the full exploitation of animal manure, not only for biogas, but also in the production of biofertilizer. In addition, great importance is given to the appropriate treatment of waste in order to prevent the pollution of water resources and the emission of greenhouse gases.

With the data obtained from this study, the conclusion can be drawn that the poultry litter produced in the southwest region of the state of Paraná is composed of nitrogen $(\mathrm{N}=26.60$ $\mathrm{g} / \mathrm{kg}$ ), phosphorus $(\mathrm{P}=13.60 \mathrm{~g} / \mathrm{kg})$, potassium $(\mathrm{K}=26.30 \mathrm{~g} / \mathrm{kg})$, calcium $(\mathrm{Ca}=23.60 \mathrm{~g} / \mathrm{kg})$, magnesium $(\mathrm{Mg}=5.07 \mathrm{~g} / \mathrm{kg})$ and sulfate $\left(\mathrm{SO}_{4}\right.$ $=4,85 \mathrm{~g} / \mathrm{kg}$ ).

The biofertilizer presented macro and micronutrients that could be assimilated by plants, such as: nitrogen, phosphorus, potassium, calcium, magnesium, sodium, iron, boron, copper, zinc and manganese. Its $\mathrm{pH}$ may vary from 6.58 to 802 , suggesting that the fermentation process was adequate, 
since lower $\mathrm{pH}$ rates promote an incomplete fermentation because they allow the generation of acids capable of inhibiting the fermentation process.

The macro and micronutrients of the produced biofertilizers differed statistically among themselves in the effluents evaluated in relation to the affluent of the system. The levels of nitrogen and phosphorus were the ones that had the highest results in the PL+B treatment, differing significantly from the $\mathrm{PL}+\mathrm{B}+\mathrm{W}$ and $\mathrm{PL}+\mathrm{W}$ treatments.

The use of poultry litters as fertilizer is therefore economically desirable, since it represents an internal asset of the rural property containing a high concentration of nutrients.

\section{Conflicts of interest}

The authors declare there are no ethical, publishing of financial conflicts of interest regarding the data of this study.

\section{References}

Ancona, Lh. Moñoz, R. 1994. Elaboración de una composta con subproductos avícolas. Indústria Avícola, 41(3): 1820.

Bataglia, O.G. 1983. Métodos de análises químicas de plantas. Campinas: Instituto Agronômico, 48 p.

Bellaver, C., Palhares, C.P. 2003. Uma visão sustentável sobre a utilização da cama de aviário. Avicultura Industrial, 6: 1418.

Bettiol, W., Tratch, R., Galvao, J.A.H. 1998. Controle de doenças de plantas com biofertilizantes, Jaguariuna: EMBRAPA- CNPMA - 22 p.

Caetano, L. 1991. Metodologia para estimativa da produção contínua de biogás em biodigestores modelo indiano. Botucatu, 1991, 112p. Tese (Doutorado em Energia na Agricultura). FCA/UNESP. Botucatu- São Paulo Brasil.

Carneiro, S.L. Ulbrich, A.C. Falkowski, T. Carvalho, C., Soares, Jr. S. Llanillo, R.F. 2004. Frango de corte - integração produtor / indústria. Programa Paraná 12 meses. Curitiba. PR - Brasil. 320p.

Castro, P.R.C., Hiroce, R. 1988. Aplicacao de biofertilizante em cultura de videira com sintomas de declinio. Summa Phytopathologica, 14(1-2):58-64.

Fernandes, A.L.T., Testezlaf, R. 2002. Fertirrigacao na cultura do melao em ambiente protegido, utilizando-se fertilizantes organominerais e quimicos. Revista Brasileira de Engenharia Agrícola e Ambiental, 6(1): 45-50.

Fernandes, H.S., Martins, S.R. 1999. Cultivo de alface em solo em ambiente protegido. Informe agropecuário, 20(200/201): 56-63.

Hahn, L. 2004. Processamento da cama de aviário e suas implicações nos agroecossistemas. Dissertação de Mestrado. 131p. 2004. Curso de Pósgraduação em Agroecossistemas, Centro de Ciências Agrárias, Universidade Federal de Santa Catarina. Florianópolis. Brasil.

Malavolta, E., Vitti, G.C., Oliveira, S.A. 1991. Avaliação do estado nutricional das plantas: princípios e aplicações. 2.ed. Piracicaba: Potafos, 319 p.

Meirelles, L., Bracagioli Neto, A., Meirelles, A.L., Gonçalves, A., Guazzelli, M.J., Volpato, C., Bellé, N. 1997. Biofertilizantes enriquecidos: caminho da nutrição e proteção das plantas. Ipê: Centro de Agricultura Ecológica, CAE Ipê. $12 \mathrm{p}$.

Ncsu - North Carolina State University Poultry manure as a fertilizer source. Biological and Agricultural Engineering. 2003. Disponível em: 
http://ces.soil.ncsu.edu/soilscienc/body.

htm. Acesso em: 15.09.2014.

Pinheiro, S., Barreto, S.B. 1996. MB4 Agricultura sustentável, trofobiose e biofertilizantes. Porto Alegre: Junquira Candiru. 276p.

Sánchez, E., Borja, R., Weiland, P., Travieso, L., Martín, A. 2001. Effect of substrate concentration and temperature on the anaerobic digestion of piggery waste in a tropical climate. Process Biochem., 37: 483-489.

Santos, A.C., Akiba, F. 1996. Biofertilizantes líquidos: uso correto na agricultura alternativa. Seropédica: UFRRJ, Impr. Univer. 35p.

Santos, A.C., Akiba, F. 1996. Biofertilizantes líquidos: uso correto na agricultura alternativa. Seropédica: Imprensa Universitária/UFRRJ. 35p.

Santos, A.C.V. 1991. Efeitos nutricionais e fitossanitários do biofertilizante líquido a nível de campo. Revista Brasileira de Fruticultura, 13(4): 275 - 279.

Santos, A.CV.. 1992. Biofertilizante líquido, o defensivo da natureza. Niterói: Emater - Rio de Janeiro - Brasil. 16 p.

Seixas, J. 1980. Construção e funcionamento de biodigestores. Brasília: EMBRAPA -
DID, EMBRAPA-CPAC. Circular técnica 4, 19p.

Silva, D.J. 1983. Análise de alimentos: métodos químicos e biológicos. Viçosa: UFV. $166 \mathrm{p}$.

Souza, J.L., Resende, P. 2003. Manual de Horticultura orgânica. Vicosa: Aprenda Facil. 564 p.

Steil, L. 2001. Avaliação do uso de inóculos na biodigestão anaeróbia de resíduos de aves de postura, frangos de corte e suínos. 2001. 108f. Dissertação (Mestrado em Biotecnologia), - Instituto de Química, Universidade Estadual Paulista, Araraquara, São Paulo - Brasil.

Timm, P.J., Gomes, J.C.C., Morselli, T.B. 2004. Insumos para agroecologia: Pesquisa em vermicompostagem e producao de biofertilizantes liquidos. Revista Ciência \& Ambiente, 29: 123129.

Tratch, R. 1996. Efeito de Biofertilizantes sobre fungos fitopatogênicos. Dissertacao de Mestrado. 60 p. Area de Concentracao: Protecao de Plantas, Faculdade de Ciencias Agronomicas "Campus" Botucatu (UNESP), Sao Paulo - Brasil.

\section{How to cite this article:}

Sideney Becker Onofre, Ivan Carlos Bertoldo, Dirceu Abatti and Douglas Refosco. 2017. Physico-Chemical Characteristics of the Biofertilizer Produced Anearobically in a Biodigester Using Poultry Litter as Substrate. Int.J.Curr.Microbiol.App.Sci. 6(2): 1830-1839. doi: http://dx.doi.org/10.20546/ijcmas.2017.602.206 